ISSN : $2354-6034$ (Print)

ISSN : 2599 - 0187 (Online)

\title{
PENGARUH JENIS PRODUK PAKAIAN DAN PENETAPAN HARGA TERHADAP PERMINTAAN KONSUMEN DI KOTA PALANGKA RAYA (STUDI KASUS di TOKO YULIA)
}

\author{
Fuad Muhajirin Farid ${ }^{1}$ dan Siti Maryam \\ email: foead.mf@gmail.com; siti.maryam1796@gmail.com
}

\begin{abstract}
Abstrak
Salah satu produk yang perkembangannya sangat cepat pada zaman sekarang ini berhubungan dengan pakaian. Pakaian adalah kebutuhan pokok manusia selain makanan dan tempat tinggal (rumah). Manusia membutuhkan pakaian untuk melindungi dan menutup dirinya. Namun seiring dengan perkembangan kehidupan manusia, pakaian juga digunakan sebagai simbol status, jabatan, ataupun kedudukan seseorang yang memakainya. Bisnis penjualan pakaian sekarang ini memang sangat berkembang, ini terbukti dengan semakin banyaknya muncul butik, distro dan online shop yang menjual berbagai jenis pakaian. Fenomena ini di akibatkan karena meningkatnya permintaan pasar. Untuk itu penelitian ini akan difokuskan pada pengaruh jenis produk pakaian dan penetapan harga terhadap permintaan produk di Kota Palangka Raya dengan studi kasus di Toko Yulia. Tujuan penelitian ini untuk mengetahui pengaruh jenis produk pakaian dan penetapan harga terhadap permintaan produk.

Jenis penelitian ini merupakan jenis penelitian kuantitatif. Penelitian ini merupakan penelitian yang dilakukan secara langsung di lapangan atau bisa disebut dengan field research dengan menggunakan analisis regresi linier berganda. Sampel penelitian berjumlah 400 responden konsumen yang membeli di Toko Yulia. Metode pengumpulan data penulis menggunakan angket.

Hasil dari penelitian ini menunjukkan nilai $F$ sebesar 241,559. Apabila menggunakan $F$ tabel sebesar 0,0983 maka artinya ada pengaruh secara signifikan antara jenis produk pakaian dan penetapan harga secara simultan terhadap permintaan produk. Hasil penelitian ini juga menunjukkan bahwa nilai $R$ Square sebesar 0,549 yang dapat diartikan bahwa variabel jenis produk pakaian dan penetapan harga mempunyai pengaruh sebesar $54,9 \%$ terhadap variabel permintaan produk, sedangkan 45,1\% lainnya dipengaruhi oleh faktorfaktor di luar dari variabel jenis produk pakaian dan penetapan harga. Dengan model Regresi linier berganda $Y=4,854+0,163 X_{1}+0,363 X_{2}+\varepsilon$
\end{abstract}

\section{Kata kunci: permintaan produk, jenis dan penetapan harga, Regresi}

\section{PENDAHULUAN}

Pemasaran merupakan proses kegiatan mulai dari pemilihan pasar, penciptaan produk, penetapan harga, sistem distribusi, hingga mempromosikan. Pemasaran merupakan bagian

${ }^{1}$ Dosen Universitas Lambung Mangkurat Banjarmasin 
penting dalam suatu perusahaan yang sekarang ini sedang menghadapi persaingan yang semakin tajam dan keadaan ekonomi yang tidak menentu. Dengan banyaknya persaingan yang ada dipasar maka perusahaan dituntut mengerti akan kebutuhan dan keinginan konsumennya. Pemasaran juga sebagai langkah awal yang harus dilaksanakan dalam memasarkan produk agar dapat di terima dan dikenal oleh masyarakat luas. Dengan demikian semakin banyak jenis barang maka perusahaan dituntut lebih memperhatikan bidang pemasaran, karena konsumen saat ini kritis dan cerdas dalam memilih produk mana yaang mereka butuhkan dan harga yang sesuai dengan kualitas produk dan manfaatnya untuk mereka.

Upaya yang perlu dilakukan perusahaan untuk dapat bertahan dan bersaing adalah dengan memahami perilaku konsumen yang akan mempengaruhi keputusan permintaan produk, dimana salah satunya dengan menawarkan jenis barang. Pengertian barang menurut Fandy Tjiptono adalah produk yang berwujud fisik sehingga dapat bisa dilihat, disebut, dirasa, dipegang, disimpan, dan perlakuan fisik lainnya. Konsumen akan membeli produk kalau merasa cocok. Karena itu, produk harus disesuaikan dengan keinginan atau kebutuhan konsumen, agar pemasaran produk berhasil. Barang atau produk mempunyai berbagai macam jenis sehingga untuk memudahkan dalam pengenalan atau pemahaman terhadap barang dapat diklasifikasikan atau digolongkan yaitu berdasarkan karakteristik/sifat, berdasarkan wujud, dan berdasarkan wujud, dan berdasarkan tujuan atau pemakaian. Berdasarkan karakteristik/sifat yaitu barang tahan lama, barang tidak tahan lama, dan jasa. Berdasarkan wujud yaitu barang nyata atau berwujud dan barang tidak nyata atau tidak berwujud. ${ }^{2}$ Sedangkan barang berdasarkan tujuan atau pemakaian adalah barang konsumsi yaitu apa yang dibeli oleh konsumsi akhir untuk konsumen pribadi dan barang industri yaitu barang yang dibeli untuk diproses lebih lanjut atau dipergunakan dalam menjalankan bisnis. ${ }^{3}$

Permintaan produk tidak hanya mengandalkan tersedianya banyaknya jenis barang saja tetapi dipengaruhi juga oleh penetapan harga. Menurut Thamrin Abdullah dan Francis Tantri penetapan harga merupakan suatu masalah ketika perusahaan harus menentukan harga untuk pertama kali. Hal ini terjadi ketika perusahaan mengembangkan atau memperoleh suatu produk baru, ketika ia memperkenalkan produk lamanya ke saluran distribusi baru atau ke daerah geografis baru, dan ketika ia melakukan tender memasuki suatu tawaran kontrak kerja yang baru. Perusahaan juga harus mempertimbangkan banyak faktor dalam mengambil keputusan penetapan harga.

Keputusan penetapan harga harus konsisten dengan strategi pemasaran perusahaan dan pasar sasarannya serta penentuan jenis barang. Hal ini karena konsumen memiliki standar sendiri terhadap suatu harga. Pengalaman yang baik atau buruk terhadap jenis barang dan penetapan harga akan mempengaruhi konsumen dalam permintaan produk. Sehingga perusahaan dituntut menetapkan harga yang disesuaikan dengan produk. Perusahaan dengan penetapan harga yang sesuai dengan produk akan lebih unggul dari perusahaan lain. Perusahaan harus dapat memahami gaya hidup masyarakat, selera masyarakat dan

${ }^{2}$ Fajar Laksana, Manajemen Pemasaran: Pendekatan Pratis, Yogyakarta: GRAHA ILMU, 2008, h. 68-69.

${ }^{3}$ Thamrin Abdullah \& Francis Tantri, Manajemen Pemasaran, Jakarta: PT Rajagrafindo Persada, 2013, h. 155. 
lingkungan masyarakat saat ini agar jenis barang yang ditawarkan dapat diterima konsumen, sehingga harga yang ditetapkan berhasil untuk memenuhi keinginan konsumennya.

Zaman yang berkembangnya begitu cepat seperti saat ini telah banyak membawa pengaruh yang sangat besar pada perusahaan. Salah satu produk yang perkembangannya sangat cepat yaitu yang berhubungan dengan pakaian. Pakaian merupakan hal yang tidak akan pernah lepas dari perhatian setiap individu karena dapat menjadi sebuah penilaian terhadap karakter seseorang. ${ }^{4}$ Pakaian adalah kebutuhan pokok manusia selain makanan dan tempat tinggal (rumah). Manusia membutuhkan pakaian untuk melindungi dan menutup dirinya. Namun seiring dengan perkembangan kehidupan manusia, pakaian juga digunakan sebagai simbol status, jabatan, ataupun kedudukan seseorang yang memakainya.

Bisnis penjualan pakaian sekarang ini memang sangat berkembang, ini terbukti dengan semakin banyaknya muncul butik, distro dan online shop yang menjual berbagai jenis pakaian. Melihat peluang tersebut bisnis penjual pakaianpun semakin banyak bermunculan salah satunya yaitu Toko Yulia, Toko Yulia adalah perusahaan yang bergerak dibidang penyedia produk fashion untuk keluarga yang cukup besar di pasar besar, Toko Yulia memiliki banyak pilihan produk seperti pakaian jadi, aksesoris, perlengkapan bayi, perlengkapan shalat, pakain dalam, dll.Melihat dari fenomena ini, keingintahuan peneliti untuk mengetahui pengaruh jenis barang pakaian dan penetapan harga terhadap permintaan produk khususnyadi Toko Yulia di Kota Palangka Raya.

\section{LANDASAN TEORI}

Menurut Kotler dan Amstrong. Pengembangan suatu produk atau jasa melibatkan pendefinisian manfaat yang akan ditawarkan oleh produk atau jasa tersebut. Manfaat ini dikomunikasikan dan dihantarkan oleh atribut produk seperti kualitas, fitur, serta gaya dan desain produk.

1. Kualitas Produk adalah salah satu sarana positioning utama pemasar. Kualitas mempunyai dampak langsung pada kinerja produk. Oleh karena itu, kualitas berhubungan erat dengan nilai dan kepuasan pelanggan.

2. Fitur Produk, sebuah produk dapat ditawarkan dalam beragam fitur. model dasar, model tanpa tambahan apa pun, merupakan titik awal. Perusahaan dapat menciptakan tingkat model yang lebih tinggi dengan menambahkan lebih banyak fitur. Fitur adalah sarana kompetitif untuk mendiferensiasikan produk dari produk pesaing.

3. Gaya dan Desain Produk. Cara lain untuk menambah niai pelanggan adalah melalui gaya dan desain produk yang berbeda. Desain adalah konsep yang lebih besar dari pada gaya. Gaya hanya menggambarkan penampilan produk. Gaya bisa menarik atau membosankan. Gaya sensasional bisa menarik perhatian dan menghasikan estetika yang indah. Tetapi gaya tersebut tidak benar-benar membuat kinerja produk menjadi lebih baik. Tidak seperti gaya, desain lebih dari sekedar kulit luar. Desain adalah jantung

${ }^{4}$ Sri Budi Lestari, Fashion Sebagai Komunikasi Identitas Sosial di Kalangan Mahasiswa, Jurnal Pengembangan Humaniora Vol. 14 No. 3, Desember 2014, h. 225. 
produk. Desain yang baik tidak hanya mempunyai andil penampilan produk tetapi juga dalam manfaatnya. ${ }^{5}$

Pertimbangan utama dalam penetapan harga dapat dijelaskan sebagai berikut:

1. Penetapan pelanggan terhadap nilai-nilai produk menjadi batas atau harga. Apabila pelanggan menganggap bahwa harga lebih besar daripada nilai produk, mereka tidak akan membeli produk.

2. Dalam penetapan harga di antara dua keadaan ekstrem ini, perusahaan harus mempertimbangkan, sejumlah faktor internal dan eksternal lainnya, termasuk strategi dan bauran pemasaran secara keseluruhan, kondisi pasar dan pesaing, persepsi nilai oleh pelanggan dan biaya-biaya produk, mendapat pertimbangan yang seksama bagi prusahaan, baik secara internal maupun eksternal.

3. Pelanggan menentukan apakah harga suatu produk sudah tepat. Dengan demikian, dapat disimpulkan bahwa keputusan penetapan harga harus dimulai dari nilai pelanggan. Penetapan harga hendaklah berorientasi pada pelanggan. ${ }^{6}$

Menurut Ibn Taimiyah ada beberapa faktor yang berpengaruh terhadap permintaan terhadap suatu barang dan pengaruhnya terhadap harga yaitu:

1. Harga barang itu sendiri dan barang substitusi. Jika harga barang tinggi, permintaan terhadap barang akan meningkat.

2. Keinginan penduduk terhadap jenis barang yang berbeda dan berubah-ubah. Keinginan ini tergantung pada berlimpah atau terbatasnya stok barang (mathlub), biasanya bila stoknya menipis maka permintaan penduduk terhadap barang itu meningkat ketimbang apabila stok barang berlimpah.

3. Perubahan juga tergantung pada jumlah konsumen, jika jumlah konsumen yang minat terhadap suatu barang meningkat, maka harga akan naik dan sebaliknya jika konsumen yang minat terhadap suatu barang menurun maka harga akan turun pula.

4. Permintaan juga dipengaruhi oleh menguat atau melemahnya tingkat kebutuhan atas suatu barang, jika kebutuhan tinggi, harga juga akan tinggi, dan jika kebutuhan terhadap barang menurun maka harga juga akan menurun.

5. Harga juga di pengaruhi oleh tujuan dari kontrak jual beli, jika pembayaran dilakukan dengan pembayaran tangguh, maka harga akan naik.

6. Pendapatan rumah tangga dan pendapatan rata-rata masyarakat. ${ }^{7}$

\section{METODE}

\section{Lokasi dan Sampel Penelitian}

${ }^{5}$ Faedah, Nur, Pengaruh Produk Dan Harga Terhadap Keputusan Pembelian Pakaian Lea Pada Showroom Lea Di Samarinda, Skripsi, Surabaya: Universitas Negeri Surabaya, 2016, t.d

${ }^{6}$ Kotler, Phillip dan Kevin Lane Keller, Manajemen Pemasaran, Terjemahan Benyamin Molan, Erlangga, Jakarta, 2009.

${ }^{7}$ Rozalinda, Ekonomi Islam "Teori dan Aplikasinya pada Aktivitas Ekonomi”, Jakarta: PT RajaGrafindo Persada, 2014, h 69. 
Penelitian ini merupakan penelitian kuantitatif yang dilakukan secara langsung dilapangan. Lokasi penelitian ini bertempat di Toko Yulia Pasar Payang Sari Permai Kota Palangka Raya. Dan sampel pada penelitian ini adalah konsumen dari Toko Yulia sebanyak 400 responden. Adapun teknik sampling yang digunakan adalah Simple Random Sampling dengan penentuan banyaknya sampel menggunakan rumus Taro Yamane sebagai berikut:

$$
n=\frac{N}{N \cdot d^{2}+1}
$$

Ket:

$$
\begin{array}{ll}
n & \text { : Banyak Sampel } \\
N & \text { : Banyak Populasi } \\
d^{2} & \text { : nilai Presisi yang di tetapkan. }
\end{array}
$$

\section{Variabel Penelitian}

Variabel dalam penelitian ini terdiri dari 2 variabel, masing-masing variabel Independent (bebas) yaitu, Jenis Produk Pakaian (x1) dan Penetapan Harga (x2). Sedangkan Variabel Dependent (terikat) adalah Permintaan Produk (y). Dengan menetapkan hipotesis penelitian sebagai berikut:

$\mathrm{H}_{0} \quad$ : Tidak Ada Pengaruh antara jenis Produk Pakaian (x1) dan Penetapan Harga (x2) terhadap Permintaan Produk (y).

$\mathrm{H}_{\mathrm{a}} \quad$ : Ada Pengaruh antara jenis Produk Pakaian (x1) dan Penetapan Harga (x2) terhadap Permintaan Produk (y).

\section{Analisis Data}

Pengumpulan data menggunakan teknik angket/kuisioner dengan cara menyebarkan pada responden secara acak. Angket adalah teknik pengumpulan data melalui penyebaran kuesioner (daftar pertanyaan/isian) untuk diisi langsung oleh responden seperti yang dilakukan dalam penelitian untuk menghimpun pendapat umum. ${ }^{9}$ Alat ukur yang digunakan dalam penelitian ini adalah skala likert 1 sampai dengan 5. Setiap responden diminta untuk memberikan pendapat dan pandangan terhadap pertanyaan yang diajukan. Jawaban untuk setiap pertanyaan terdiri dari 5 kategori dengan skor sebagai berikut: 1 = Sangat Tidak Setuju (STS); 2 = Tidak Setuju; 3 = Ragu-Ragu; 4 = Setuju; 5 = Sangat Setuju. ${ }^{10}$ Analisis data yang digunakan adalah Analisis regresi linier berganda. Analisis regresi linierberganda ialah suatu alat analisis peramalan nilai pengaruh dua variabel bebas atau lebih terhadap variabel terikat untuk membuktikan ada atau tidaknya hubungan fungsi atau hubungan kausal antara dua variabel bebas atau lebih $\left(\mathrm{X}_{1}\right),\left(\mathrm{X}_{2}\right),\left(\mathrm{X}_{3}\right), \ldots,\left(\mathrm{X}_{\mathrm{n}}\right)$ dengan satu variabel terikat $(\mathrm{Y})$. Dengan model regresi sebagai berikut:

\footnotetext{
${ }^{8}$ Riduwan, Metode dan Teknik Menyusun Tesis, Bandung: Alfabeta, 2010, h. 65.

${ }^{9}$ Abdurrahman Fathoni, Metodologi penelitian dan Teknik Penulisan Skripsi, Jakarta: PT Rineka Cipta, 2006, h. 111.

${ }^{10}$ Riduwan \& Sunarto, Pengantar Statistika untuk penelitian: pendidikan, sosial, komunikasi, ekonomi, dan bisnis, Bandung: Alfabeta, 2007, h. 21
} 


$$
Y=\alpha+\beta_{1} X_{1}+\beta_{2} X_{2}+\ldots+\beta_{n} X_{n}+\varepsilon
$$

Keterangan:

$Y=$ Permintaan Konsumen

$\alpha=$ Konstanta

$\beta_{1}=$ Koefisien Jenis Produk Pakaian $\left(X_{l}\right)$

$\beta_{2}=$ Koefisien Penetapan Harga $\left(X_{2}\right)$

$\varepsilon=$ standart error of estimation. ${ }^{11}$

\section{HASIL dan PEMBAHASAN}

Penelitian ini juga menggunakan analisis deskripsi responden/konsumen di Toko Yulia Kota Palangka Raya untuk mengetahui karakteristik tiap konsumen yang menjadi responden pada penelitian ini.

\section{Berdasarkan Usia}

Dari 400 orang konsumen dipilih secara acak di Toko Yulia yang diamati dengan karakteristik berdasarkan usia yang dimana dapat menjadi ukuran permintaan berbelanja di Toko Yulia, adapun sebaran konsumen berdasarkan usia dengan kelompok usia $<16$ tahun sebesar 6\% dari total sampel, usia 16 - 20 tahun sebesar 22\% dengan banyaknya konsumen 88 orang, dan konsumen didominasi dengan usia antara 21 - 25 tahun dengan jumlah 136 sebesar 34\% dari total konsumen, sedangkan pada kelompok usia 26 - 30 tahun sebesar 24\% dan konsumen dengan usia > 31 tahun sebesar 14\% dengan jumlah konsumen adalah 56 orang, keragaman konsumen berdasarkan usia tersebut dapat dilihat berdasarkan tabel 1 berikut:

Tabel 1

Sebaran konsumen Berdasarkan Usia

\begin{tabular}{|c|c|c|}
\hline Usia (tahun) & Frekuensi & $\begin{array}{c}\text { Persentase } \\
(\mathbf{\% )}\end{array}$ \\
\hline$<16$ & 24 & 6 \\
\hline $16-20$ & 88 & 22 \\
\hline $21-25$ & 136 & 34 \\
\hline $26-30$ & 96 & 24 \\
\hline$>31$ & 56 & 14 \\
\hline Jumlah & $\mathbf{4 0 0}$ & $\mathbf{1 0 0}$ \\
\hline
\end{tabular}

\section{Berdasarkan Jenis Kelamin}

Penilitan terhadap 400 orang konsumen yang diamati, karakteristik konsumen berdasarkan jenis kelamin Laki-laki sebanyak 128 orang dengan persentase 32\% dan konsumen dengan jenis kelamin Perempuan sebanyak 272 dengan persentase 68\%.

${ }^{11}$ Riduwan, Metode dan Teknik Menyusun Tesis, Bandung: Alfabeta, 2010, h.154. 
Konsumen Perempuan lebih mendominasi dalam berbelanja di Toko Yulia, sebaran konsumen berdasarkan jenis kelamin ini dapat dilihat dari tabel 2 berikut:

Tabel 2

Sebaran konsumen Berdasarkan Jenis Kelamin

\begin{tabular}{|c|c|c|}
\hline Jenis Kelamin & Frekuensi & $\begin{array}{c}\text { Persentase } \\
(\mathbf{\%})\end{array}$ \\
\hline Laki - Laki & 128 & 32 \\
\hline Perempuan & 272 & 68 \\
\hline Jumlah & $\mathbf{4 0 0}$ & $\mathbf{1 0 0}$ \\
\hline
\end{tabular}

\section{Uji Asumsi Klasik}

\section{Uji Normalitas}

Pengujian normalitas data penelitian menggunakan teknik One Sample Kolmogorovsmirnov. Adapun kriteria pengujian ini adalah apabila nilai Sign. lebih besar $(>)$ dari 0,05 maka data tersebut dinyatakan berdistribusi normal, sedangkan jika nilai Sign. lebih kecil $(<)$ dari 0,05, maka data tidak berdistribusi normal. Berdasarkan pengujian menggunakan SPSS didapatkan hasil uji normalitas dengan nilai Sign. $(0,082)>0,05$, maka dapat disimpulkan bahwa data berdistribusi normal ditunjukkan pada Tabel 3 berikut :

\section{Tabel 3}

\begin{tabular}{|ll|r|}
\hline \multicolumn{2}{|c|}{ One-Sample Kolmogorov-Smirnov Test } \\
\hline $\mathrm{N}$ & $\begin{array}{r}\text { Unstandardiz } \\
\text { ed Residual }\end{array}$ \\
Normal Parameters ${ }^{\mathrm{a}, \mathrm{b}}$ & Mean & 400 \\
& Std. Deviation & .0000000 \\
Most Extreme Differences & Absolute & 2.43529996 \\
& Positive & .063 \\
& Negative & .063 \\
Kolmogorov-Smirnov Z & & -.055 \\
Asymp. Sig. (2-tailed) & & 1.263 \\
\end{tabular}

a. Test distribution is Normal.

b. Calculated from data. 


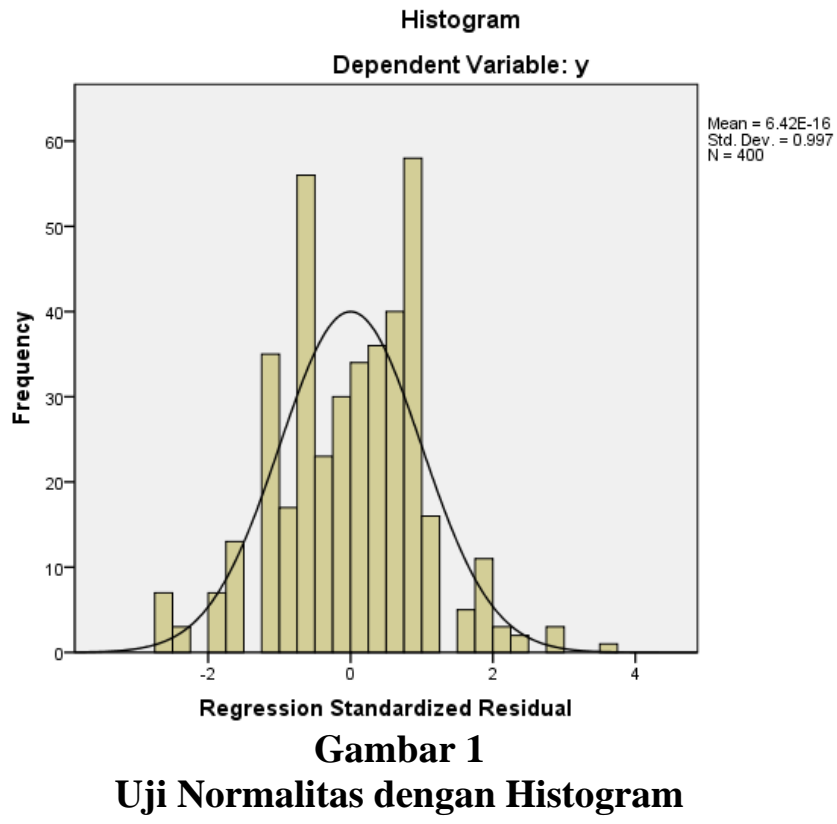

Histogram dari hasil pengujian normalitas pada gambar 1 juga menunjukkan kecenderungan data membentuk kurva lonceng yang dimana menunjukan bahwa data berdistribusi normal.

\section{Regresi Linier Berganda}

Analisis Regresi Linier Berganda digunakan untuk mengetahui pengaruh atau hubungan secara linier dari dua atau lebih variabel independent (bebas) terhadap satu variabel dependent (terikat).

\begin{tabular}{|c|c|c|c|c|c|c|}
\hline \multicolumn{7}{|c|}{ Coefficients $^{a}$} \\
\hline \multirow[t]{2}{*}{ Mod } & & \multicolumn{2}{|c|}{ Unstandardized Coefficients } & \multirow{2}{*}{$\begin{array}{c}\begin{array}{c}\text { Standardized } \\
\text { Coefficients }\end{array} \\
\text { Beta }\end{array}$} & \multirow[b]{2}{*}{$\mathrm{t}$} & \multirow[b]{2}{*}{ Sig. } \\
\hline & & $B$ & Std. Error & & & \\
\hline \multirow[t]{3}{*}{1} & (Constant) & 4.854 & .928 & & 5.230 & .000 \\
\hline & Jenis Barang Pakaian & .163 & .056 & .160 & 2.923 & .004 \\
\hline & Penetapan Harga & .368 & .033 & .609 & 11.131 & .000 \\
\hline
\end{tabular}

a. Dependent Variable: Permintaan Barang

Tabel 4 Hasil Pengujian Regresi Linier Berganda

Hasil pengujian Regresi pada tabel 4 dapat diinterprestasikan bahwa model atau persamaan regresi linier berganda dari penelitian ini adalah:

$$
Y=4,854+0,163 X_{1}+0,363 X_{2}+\varepsilon
$$

Pengujian Hipotesis penelitian juga dapat dilihat dari tabel 4. Uji t digunakan untuk mengetahui apakah secara parsial variabel Jenis Produk Pakaian dan variabel Penetapan Harga berpengaruh signifikan atau tidak terhadap variable Permintaan Konsumen. Variabel Jenis Produk Pakaian $\left(X_{I}\right)$ pada tabel 4 nilai thitung adalah 2,923, dimana thitung $>t_{\text {tabel }}(2,923>$ 1,966) dan nilai Sign. $(0,004)<0,05$ maka Hipotesis nol ditolak, sehingga variabel Jenis Produk Pakaian $\left(X_{l}\right)$ secara parsial berpengaruh secara signifikan terhadap Permintaan Konsumen $(Y)$ di Toko Yulia. 
Variabel Penetapan Harga $\left(X_{2}\right)$ juga berpengaruh signifikan secara parsial terhadap permintaan Konsumen $(Y)$ di Toko Yulia, ini dijelaskan pada tabel 4 yang dimana nilai thitung $>$ tabel $(11,131>1,966)$ dan nilai sign. $(0,000)<0,05$ maka tolak Hipotesis nol. Selanjutnya dilakukan uji F guna menguji secara simultan antara variable independent yaitu variabel Jenis Produk Pakaian $\left(X_{1}\right)$ dan Penetapan Harga $\left(X_{2}\right)$ terhadap variabel dependent yaitu Variabel Permintaan Konsumen ( $Y$ ). Untuk Uji F menggunakan tabel Analysis of Variance seperti pada tabel 5 berikut:

\begin{tabular}{|rl|r|r|r|r|r|}
\hline \multicolumn{1}{|c|}{ ANOVA $^{\mathrm{b}}$} \\
\hline 1 & \multicolumn{1}{|c|}{$\begin{array}{c}\text { Sum of } \\
\text { Squares }\end{array}$} & \multicolumn{1}{|c|}{$\mathrm{df}$} & Mean Square & \multicolumn{1}{c|}{$\mathrm{F}$} & Sig. \\
\hline & Regression & 2879.656 & 2 & 1439.828 & 241.559 & $.000^{\mathrm{a}}$ \\
& Residual & 2366.344 & 397 & 5.961 & & \\
& Total & 5246.000 & 399 & & & \\
\hline
\end{tabular}

a. Predictors: (Constant), Penetapan Harga, Jenis Barang Pakaian

b. Dependent Variable: Permintaan Barang

\section{Tabel 5. Analysis of Variance}

Berdasakan tabel 5 diketahui bahwa $F_{\text {hitung }}$ adalah 241,559 dan $F_{\text {tabel }}$ dengan nilai 0,0984, sehingga disimpulkan Fhitung $>F_{\text {tabel }}(241,559)>(0,0984)$ dengan nilai sign. $(0,000)<$ 0,05, maka Hipotesis nol ditolak yang artinya bahwa variabel Jenis Produk Pakaian $\left(X_{I}\right)$ dan Penetapan Harga $\left(X_{2}\right)$ terhadap Permintaan Konsumen $(Y)$ di Toko Yulia berpengaruh signifikan secara simultan.

Berdasarkan Uji t dan Uji F menjelaskan bahwa variabel independent yaitu Jenis Produk Pakaian $\left(X_{1}\right)$ dan Penetapan Harga $\left(X_{2}\right)$ terhadap variabel dependent Permintaan Konsumen $(Y)$ berpengaruh signifikan baik secara parsial maupun simultan. Selanjutnya melakukan koefisien determinasi ( $R$ square) yang digunakan untuk mengetahui keeratan antara dua variabel atau mengetahui seberapa besar pengaruh variabel independent terhadap variabel dependent. Pengujian $R$ square ini disajikan pada tabel 6 berikut :

\section{Tabel 6. Pengujian $R$ square}

Model Summary

\begin{tabular}{|l|l|l|r|r|}
\hline Model & $\mathrm{R}$ & $\mathrm{R}$ Square & \multicolumn{1}{c|}{$\begin{array}{c}\text { Adjusted R } \\
\text { Square }\end{array}$} & $\begin{array}{c}\text { Std. Error of } \\
\text { the Estimate }\end{array}$ \\
\hline 1 & $.741^{\mathrm{a}}$ & .549 & .547 & 2.441 \\
\hline
\end{tabular}

a. Predictors: (Constant), Penetapan Harga, Jenis Barang Pakaian

Berdasarkan tabel 6 ini dapat disimpulkan bahwa nilai koefisien kolerasi $(R)$ sebesar 0,741 yang artinya hubungan antara variabel Jenis Produk Pakaian $\left(X_{I}\right)$ dan Penetapan Harga $\left(X_{2}\right)$ terhadap variabel Permintaan Konsumen ( $Y$ ) cukup erat. Sedangkan koefisien determinasi ( $R$ square) memiliki nilai 0,549 yang artinya persentase pengaruh variabel Jenis Produk Pakaian $\left(X_{1}\right)$ dan Penetapan Harga $\left(X_{2}\right)$ terhadap variabel Permintaan Konsumen $(Y)$ sebesar 54,9\% dan 45,1\% dipengaruhi oleh variabel independent lainnya. 


\section{Kesimpulan dan Saran}

\section{Kesimpulan}

1. Variabel Jenis Produk Pakaian $\left(X_{1}\right)$ nilai thitung adalah 2,923, dimana thitung $>$ tabel $(2,923>$ 1,966) dan nilai Sign. $(0,004)<0,05$ maka Hipotesis nol ditolak, sehingga variabel Jenis Produk Pakaian $\left(X_{1}\right)$ secara parsial berpengaruh secara signifikan terhadap Permintaan Konsumen $(Y)$ di Toko Yulia.

2. Variabel Penetapan Harga $\left(X_{2}\right)$ juga berpengaruh signifikan secara parsial terhadap permintaan Konsumen $(Y)$ di Toko Yulia, yang dimana nilai thitung $>$ ttabel $(11,131>1,966)$ dan nilai sign. $(0,000)<0,05$ maka tolak Hipotesis nol.

3. Fhitung adalah 241,559 dan $F_{\text {tabel }}$ dengan nilai 0,0984, sehingga disimpulkan $F_{\text {hitung }}>F_{\text {tabel }}$ $(241,559)>(0,0984)$ dengan nilai sign. $(0,000)<0,05$, maka Hipotesis nol ditolak yang artinya bahwa variabel Jenis Produk Pakaian $\left(X_{1}\right)$ dan Penetapan Harga $\left(X_{2}\right)$ terhadap Permintaan Konsumen $(Y)$ di Toko Yulia berpengaruh signifikan secara simultan.

\section{Saran}

Berharap adanya penelitian lanjutan di Toko Yulia dengan variabel-variabel lain selain variabel jenis produk pakaian dan penetapan harga serta menggunakan metode analisis yang berbeda. Penelitian lanjutan diharapkan agar bisa mengetahui secara mendalam tentang variabel apa saja yang lebih berpengaruh dalam permintaan Konsumen.

\section{Daftar Pustaka}

[1] Fajar Laksana, Manajemen Pemasaran: Pendekatan Pratis, Yogyakarta: GRAHA ILMU, 2008.

[2] Thamrin Abdullah \& Francis Tantri, Manajemen Pemasaran, Jakarta: PT Rajagrafindo Persada, 2013.

[3] Sri Budi Lestari, Fashion Sebagai Komunikasi Identitas Sosial di Kalangan Mahasiswa, Jurnal Pengembangan Humaniora Vol. 14 No. 3, Desember 2014,

[4] Kotler, Phillip dan Kevin Lane Keller, Manajemen Pemasaran, Terjemahan Benyamin Molan, Erlangga, Jakarta, 2009.

[5] Rozalinda, Ekonomi Islam “Teori dan Aplikasinya pada Aktivitas Ekonomi”, Jakarta: PT RajaGrafindo Persada, 2014.

[6] Riduwan, Metode dan Teknik Menyusun Tesis, Bandung: Alfabeta, 2010.

[7] Abdurrahman Fathoni, Metodologi penelitian dan Teknik Penulisan Skripsi, Jakarta: PT Rineka Cipta, 2006.

[8] Riduwan \& Sunarto, Pengantar Statistika untuk penelitian: pendidikan, sosial, komunikasi, ekonomi, dan bisnis, Bandung: Alfabeta, 2007. 